\title{
Transformation of the Endophyte Neotyphodium with the iaaM Gene
}

\author{
Ahmad Yunus*, Shinji KaWAmata**, Tadayuki ShImanukI***, Yasuhiro Murakami*, ${ }^{*}$, \\ Yuki ICHINOSE*, Tomonori SHIRAISHI* and Tetsuji YAMADA*
}

Key words : Neotyphodium sp., endophyte, transformation, iaaM gene.

Symbiotic associations of grasses with Neotyphodium endophytes often provide the grass hosts with major fitness enhancements ${ }^{8-11)}$. These associations are considered to be mutualistic, with the plants providing nutrients for the fungi and the fungi synthesizing alkaloids that protect the plants from mammalian and insect herbivores, plant pathogens and nematodes, as well as increased drought tolerance and competitiveness ${ }^{1,2,6)}$.

The Neotyphodium endophytes of grasses are found predominantly in the intercellular spaces of the leaf sheath and are usually seed-transmitted. In nature, they are not known to cause disease or to produce external structures ${ }^{2,5)}$.

To use endophytes to endow novel functions in plants, we have attempted to introduce iaaM gene from $P$. syringae pv. savastanoi into Neotyphodium. Pseudomonas syringae pv. savastanoi, causal agent of olive and oleander knot, produces indole-3-acetic acid (IAA) from Ltryptophan (Trp) via indole-3-acetamide (IAM) as an intermediate ${ }^{3,13)}$. The so-called olive knot tumor is thought to result from abnormal plant cell multiplication at the infection site as a host response to the large amount of IAA produced by this pathogen. The genes involved in IAA biosynthesis in this pathogen are iaaM, which encodes tryptophan monooxygenase, and iaaH, which encodes indoleacetamide hydrolase ${ }^{3)}$. Production of IAA in these plant-associated microorganisms might facilitate interaction with the host. This study was designed to develop this concept in fungi, too.

The demonstration that Neotyphodium can be transformed and that the marker genes introduced were stably maintained ${ }^{5)}$, opens the way for using these fungi as a vehicle for introducing the iaaM gene into grasses. Since some extent of IAM accumulation is presumed to be automatically converted to IAA, we did not attempt to clone the $i a a H$ gene in Neotyphodium. The ability to transform Neotyphodium endophyte and the development of efficient methods for introducing the fungus back into the plant ${ }^{4)}$, offers an alternative surrogate method to transform grasses. Once the endophyte association with host plant is established in the grass, the introduced iaaM gene will be maternally transmitted as a consequence of fungal invasion by fungal hyphae of the ovule of the developing seed.

Neotyphodium protoplasts were prepared using a modification of the method as described ${ }^{14)}$. The concentration of protoplasts obtained in these experiments was $1.8 \times 10^{7} / \mathrm{ml}$. Transformation by polyethylene glycol (PEG) was done using a modification of the procedure as described $^{12)}$. Twenty $\mu$ l of a $40 \%$ PEG solution $(40 \%$ PEG 4000, $50 \mathrm{mM} \mathrm{CaCl}_{2} \cdot 2 \mathrm{H}_{2} \mathrm{O}, 1 \mathrm{M}$ sorbitol, $50 \mathrm{mM}$ Tris- $\mathrm{HCl} \mathrm{pH} \mathrm{8.0),} 2 \mu 1$ spermidine $(50 \mathrm{mM}), 5 \mu 1$ heparin $(5 \mathrm{mg} / \mathrm{ml})$ and $10 \mu \mathrm{g}$ of DNA $\left(2 \mu \mathrm{g} / \mu \mathrm{l}\right.$ in $\left.\mathrm{H}_{2} \mathrm{O}\right)$ was added into $80 \mu 1$ of protoplasts in STC buffer (1M Sorbitol, 50 $\mathrm{mM} \mathrm{CaCl}{ }_{2} \cdot 2 \mathrm{H}_{2} \mathrm{O}, 50 \mathrm{mM}$ Tris- $\mathrm{HCl} \mathrm{pH}$ 8.0). The solution was mixed gently and incubated on ice for $30 \mathrm{~min}$, then $900 \mu 1$ of $40 \%$ PEG was added and incubated at room temperature for $15-20 \mathrm{~min}$. One hundred $\mu 1$ of this mixture was put into $5 \mathrm{ml}$ of $0.8 \%$ regeneration medium $\left(\right.$ at $50^{\circ} \mathrm{C}$ ) to overlay to a regeneration medium plate. The plate was incubated at $25^{\circ} \mathrm{C}$ overnight, then overlaid with molten $0.8 \%$ agar containing an appropriate amount of hygromycin $(200 \mu \mathrm{g} / \mathrm{ml})$. The plate was inverted and incubated in the dark at $22^{\circ} \mathrm{C}$ for 4 to 7 days. Transformation of Neotyphodium protoplasts of strain Ti 91093 with $5 \mu \mathrm{g}$ of pAY2 (Fig. 1C) gave 107 transformants. Genomic DNA was prepared from fresh mycelium $(60 \mathrm{mg})$ of each strain by the mini-preparation procedure as described ${ }^{7,15)}$, except the mycelium was first ground to a powder in liquid nitrogen. To determine the integration of the $h p h$ (hygromycin resistance gene) and iaaM genes into the genome of Neotyphodium, the DNA fragment of $h p h$ and iaaM gene was amplified by PCR with appropriate primers. The result of the PCR showed that the transformant had a signal band of 560 bp, corresponding to the size of the $h p h$ gene, and PCR

* Laboratory of Plant Pathology and Genetic Engineering, College of Agriculture, Okayama University, Tsushima, Okayama 700-8530, Japan 岡山大学農学部

** Takasago Perfumery, Inc., 1-5-1, Nishi-hachiman, Hiratsuka 254-0073, Japan＼cjkstart高砂香料株式会社

*** Laboratory of Plant Pathology, Department of Environment, National Grassland Research Institute, Nishinasuno 3292747, Japan 草地試験場

† Present address : National Institute of Agrobiological Resources, 2-1-2, Kannondai, Tsukuba 305-8602, Japan 現在： 農業生物資源研究所 
for amplifying iaaM fragment showed a signal band of $1.7 \mathrm{~kb}$ corresponding to a fragment of the iaaM gene (Fig. 2A), indicating that $h p h$ and iaaM gene had been integrated into the genome of the transformant.

Introduction of the iaaM gene into Neotyphodium protoplast by electroporation was also attempted. That is, protoplasts were washed free of media by centrifugation at $750 \times \mathrm{g}$ for $3 \mathrm{~min}$, then resuspended in $100 \mu \mathrm{l}$ sterile distilled water and pAY2 $(5 \mu \mathrm{g})$ was added. Before electroporation, this mixture was incubated on ice for $5 \mathrm{~min}$, and electroporation was performed with Gene Pulser (Bio-Rad). To develope the electroporation
A

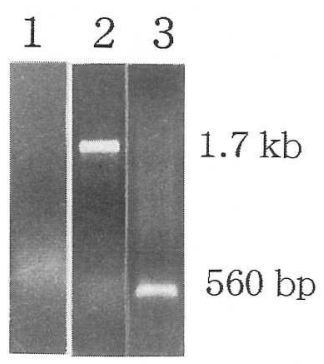

C

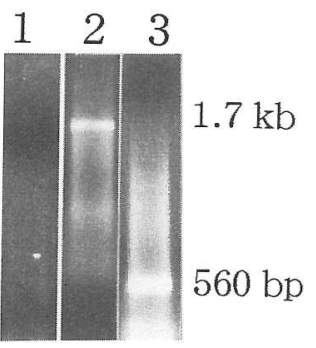

B

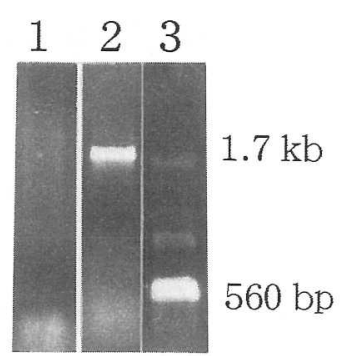

A
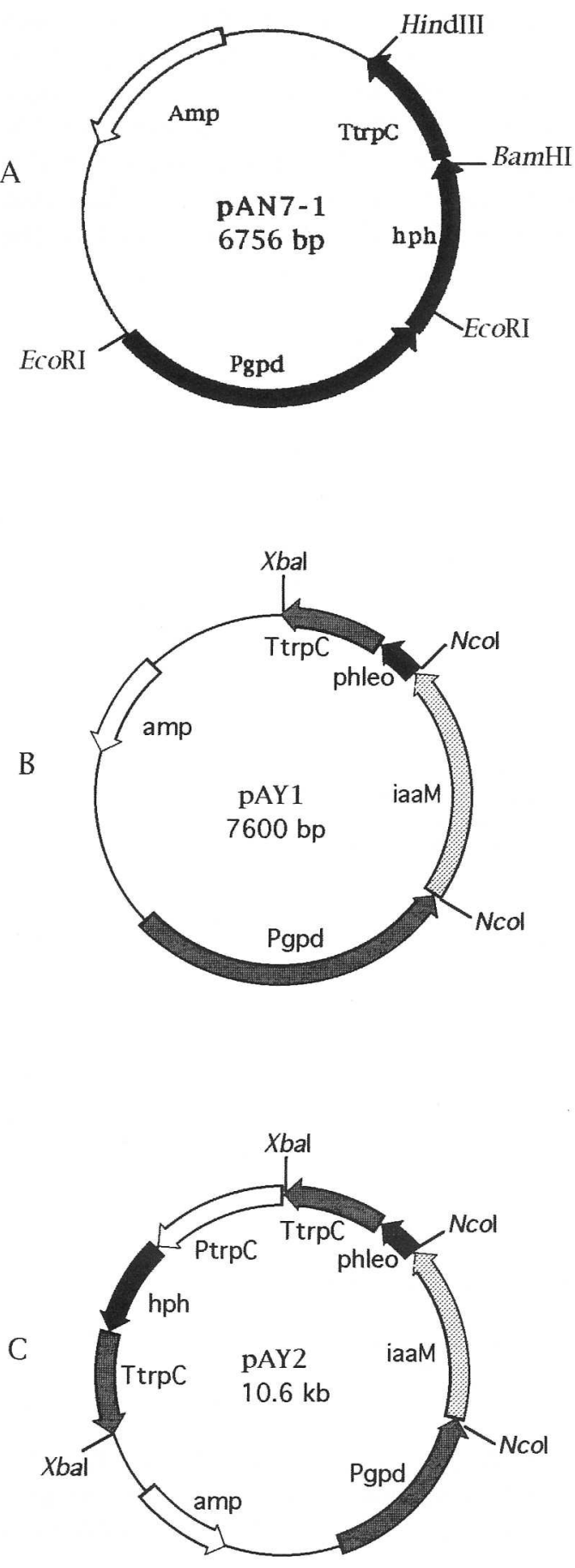

Fig. 2. PCR products of $h p h$ and iaaM gene in transformants. Genomic DNA of non-transformants (lane 1) and transformants (lane 2 and 3) of strain Ti 91093 by PEG (A), strain Ti 91093 by electroporation (B), strain TF 91006 by PEG co-transformation (C), and strain TF 91006 cotransformant by electroporation (D) were used for PCR amplification of iaaM gene (lane 1 and 2) and $h p h$ gene (lane 3). Bands at $1.7 \mathrm{~kb}$ and 560 bp indicate iaaM gene and $h p h$ gene, respectively.
Fig. 1. Map of the plasmid pAN7-1, pAY1 and pAY2. A : Plasmid pAN7-1. Restriction sites for Eco RI, BamHI, and HindIII are shown, as are the genes for ampicillin resistance ( $a m p)$, hygromycin B resistance $(h p h)$. The $h p h$ gene is fused to the Aspergillus nidulans glyceraldehyde-3-phosphate dehydrogenase promoter fragment $(\mathrm{P} g p d)$ and an $A$. nidulans trpC terminator (TtrpC). B : Plasmid vector pAY1. NcoI DNA fragment of iaaM gene is fused to the Pgpd and the T trpC at NcoI site upstream from the phleomycin in pAN8-1. C : Plasmid vector pAY2. DNA fragment of $h p h$ gene and its promoter $(\mathrm{P} t r p C)$ and terminator $(\mathrm{T} \operatorname{trp} C)$ are inserted into $X b a \mathrm{I}$ site downstream from the $\mathrm{T} \operatorname{tr} p C$ in $\mathrm{pAY} 1 . \mathrm{Ptrp} C$ indicates $A$. nidulans trpC gene promoter. Restriction sites for $N c o \mathrm{I}$ and $\mathrm{XbaI}$ are shown. 
procedure, we investigated the best conditions for electroporation with the varied capacitance and voltage. The optimal condition for Neotyphodium protoplasts was, resistance $400 \Omega$, capacitance $25 \mu \mathrm{FD}$ and voltage 2

Table 1. The effect of capacitance and voltage on number of transformants after electroporation

\begin{tabular}{ccccc}
\hline \hline \multirow{2}{*}{ Capacitor $(\mu \mathrm{F})$} & Voltage $(\mathrm{V})$ & \multicolumn{3}{c}{ Transformant* } \\
\cline { 3 - 5 } & & $\mathrm{I}$ & $\mathrm{II}$ & $\mathrm{III}$ \\
\hline 1 & 1500 & 0 & 0 & 0 \\
& 2000 & 0 & 0 & 0 \\
\multirow{3}{*}{3} & 2500 & 0 & 0 & 1 \\
& 1500 & 1 & 1 & 0 \\
25 & 2000 & 1 & 2 & 1 \\
& 2500 & 1 & 2 & 2 \\
& 1500 & 3 & 3 & 4 \\
& 2000 & 5 & 6 & 5 \\
& 2500 & 2 & 2 & 1 \\
\hline
\end{tabular}

${ }^{*} \mathrm{I}$ : experiment 1 ; II : experiment 2 ; III : experiment 3.
$\mathrm{kV} / \mathrm{cm}$. Under this condition, the highest number of transformants could regenerate on the selective medium (Table 1). After electroporation, aliquots were put into 5 $\mathrm{ml}$ of molten $0.8 \%$ regeneration medium and overlaid onto regeneration medium. The plate was incubated at $25^{\circ} \mathrm{C}$ overnight and then overlaid with $0.8 \%$ agar containing hygromycin $\mathrm{B}(\mathrm{HmB} ; 200 \mu \mathrm{g} / \mathrm{ml})$. The plate was further incubated at $22^{\circ} \mathrm{C}$ for 4 to 7 days.

Transformation by electroporation with pAY2 $(5 \mu \mathrm{g})$ of strain Ti 91093 gave three transformants. A low transformation efficiency was presumed with low protoplast regeneration frequencies. These results might indicate that transformation by PEG is more effective than that by electroporation. The development of a high efficiency transformation system for the Neotyphodium endophyte of perennial ryegrass using hygromycin resistance as a dominant selectable marker has been reported $^{5)}$. The high efficiency transformation for filamentous fungi using a PEG-based transformation system is presumably the result of using a medium that gives good regeneration of protoplasts, as well as the

A
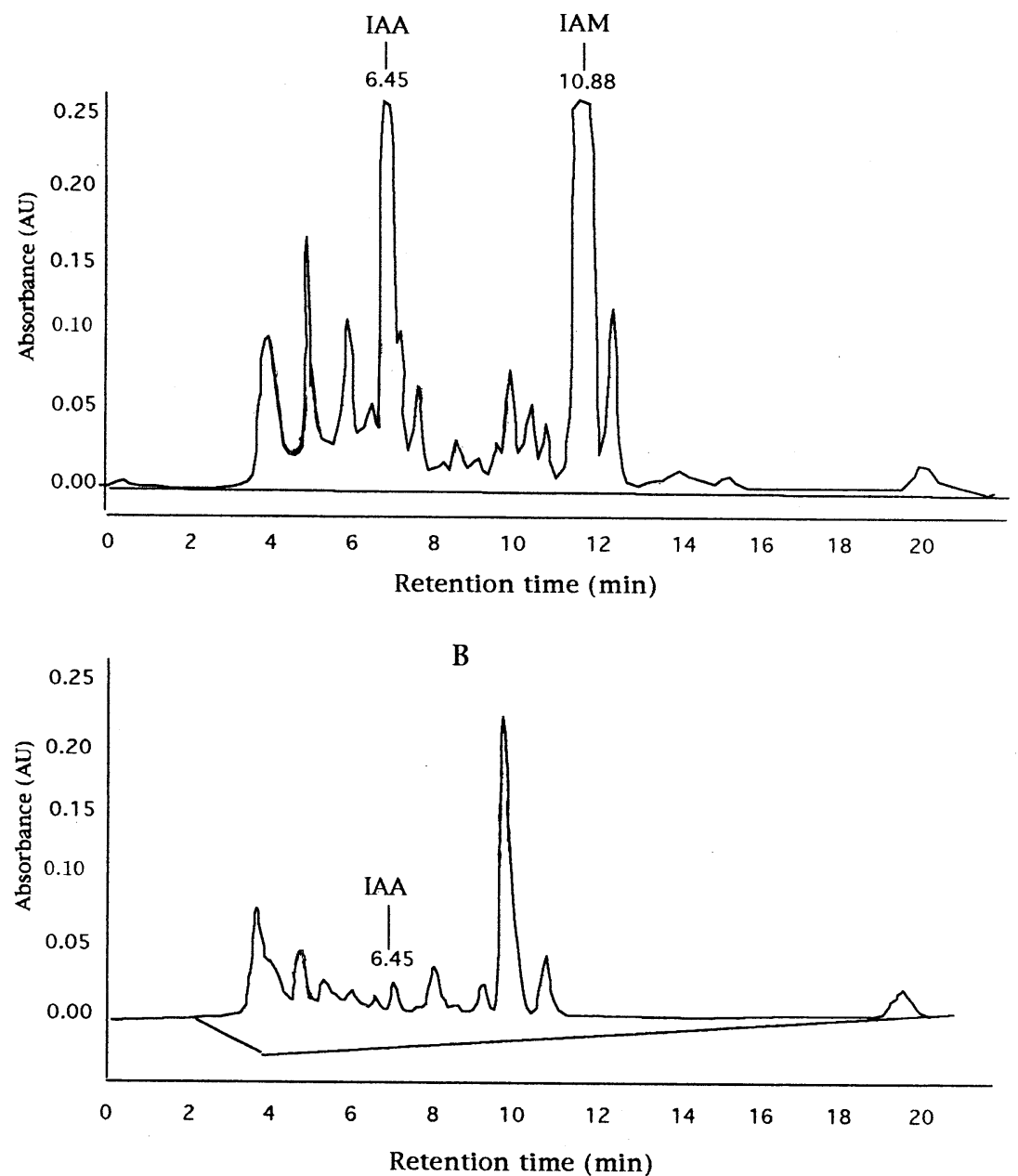

Fig. 3. Analysis of the accumulation of IAA and IAM by reverse-phase HPLC. Details are described in the text. HPLC profiles of a transformant (A) and non-transformant (B) of strain TF 91006 were shown. Mobile phase; a : Methanol, $\mathrm{b}: 1 \%$ acetic acid, $1 \%$ 1-heptance sulfonic acid sodium salt in water, $\mathrm{a}: \mathrm{b}=1: 1$. Flow rate $: 1 \mathrm{ml} / \mathrm{min}$. Detector: photodiode array monitor at $280 \mathrm{~nm}$ (L745H : Hitachi). 
inclusion of sorbitol as an osmoticum, not only during the preparation of the protoplast but also in the $40 \%$ PEG solution used in the transformation $s \mathrm{p}^{14)}$. Integration of $h p h$ and iaaM gene into the genome of Neotyphodium was confirmed by PCR as well as the transformation of strain Ti 91093 by PEG (Fig. 2B).

Co-transformation of Neotyphodium protoplast with 2 $\mu \mathrm{g}$ pAN7-1 which shows resistance to hygromycin B (Fig. 1A) and $10 \mu \mathrm{g}$ pAY1 (Fig. 1B) into strain TF 91006 gave six transformants by the PEG method, while cotransformation by electroporation gave four transformants. Integration of $h p h$ and iaaM gene into the genome of Neotyphodium was confirmed by PCR as described above (Fig. 2C, D), and normal nucleotide sequences of iaaM integrated into the genome of Neotyphodium were analysed by DNA sequencer (data not shown).

To determine expression of the iaaM gene, the amount of IAM and IAA in the culture medium was examined by HPLC after addition of $0.2 \mathrm{mM}$ L-tryptophan. The culture was centrifuged at $10,000 \times g$ for 15 $\min$ at $4^{\circ} \mathrm{C}$ to remove the cells. After centrifugation, $1 \mathrm{~N}$ $\mathrm{HCl}$ was added to the supernatant to adjust the $\mathrm{pH}$ to 3.0 , and $100 \mathrm{ml}$ of ethyl acetate was added to the supernatant to extract the indole compounds. Seventy-five $\mathrm{ml}$ of the ethyl acetate extract was evaporated to dryness and redissolved in ethanol. For HPLC analysis, samples in ethanol solution were applied to the column Inertsil ODS3 4.6 $\times 250$ (GL Science).

Accumulation of both IAM and IAA from the culture filtrate of transformant strain TF 91006 and strain Ti 91093 could be detected by HPLC. Detection by HPLC showed an accumulation of IAM and IAA in the transformant of strain TF 91006 of $56.97 \mu \mathrm{M} / \mathrm{g}$ cells and 30.26 $\mu \mathrm{M} / \mathrm{g}$ cells, respectively (Fig. 3A), while accumulation of IAM and IAA in the transformant of strain Ti 91093 was $36.42 \mu \mathrm{M} / \mathrm{g}$ cells and $21.38 \mu \mathrm{M} / \mathrm{g}$ cells, respectively. On the other hand, the accumulation of IAA in the non-transformant of strain TF 91006 was $23.12 \mu \mathrm{M} / \mathrm{g}$ cells (Fig. 3B) and of strain Ti 91093 was $18.24 \mu \mathrm{M} / \mathrm{g}$ cells. No accumulation of IAM in the culture filtrate of non transformants was detected by HPLC analysis, indicating that transformants significantly accumulated IAM. However, not all transformants showed high expression by accumulating IAM as we expected. We are currently examining the copy number and the integration of iaaM gene in the transformants. These result showed that the promoter of $A$. nidulans glyceraldehyde-3-phosphate dehydrogenase ( $\mathrm{Pg} d$ ) was enough to promote the expression of iaaM gene. A non-transformant of Neotyphodium also produced a small amount of IAA, but not IAM, although the pathway of IAA biosynthesis is still unclear. Most microorganisms carry the IAA biosynthetic pathway from tryptophan (Trp) through indole-3-pyruvic acid (IPA) and indole-3-acetaldehyde (IAAld) as intermediates ${ }^{13}$. The production of IAA is widespread in the plant kingdom, including bacteria and fungi, although the amount of IAA produc- tion and its biosynthetic pathway vary from one organism to the other ${ }^{13)}$.

Our study has indicated that introducing a foreign gene into grasses by using this fungus as a vector is possible, since the development of efficient methods for introducing the fungus back into the grasses has been established $^{4)}$. It will be interesting to examine whether IAA biosynthesis through the IAM pathway in these transformants could facilitate a better interaction with the host. If so, the IAM pathway may have a role in the interaction with host, or the beneficial effect of IAA production by these transformants may depend on the IAA biosynthesis pathway. Inoculation of grasses with these fungi and examination of the effects of the expression of iaaM gene in Neotyphodium to the association with host plants is underway.

We thank Dr. R. Oliver (School of Biological Sciences, University of East Anglia, UK) for provision of plasmid vector pAN7-1 and pAN8-1 and Dr. T. Tsuge (Faculty of Agriculture, Nagoya University) and Prof. O.C. Yoder (Cornell University, Ithaca, NY) for providing a plasmid vector, pDH25. We are much indebted to Dr. Y. Itoh (Faculty of Science, Shinshu University) for providing the transformation procedures. This study was supported in part by a Grant for "Frontier Research for the Creation of New Industries" provided by the Japanese Ministry of Agriculture, Forestry and Fisheries and also in part by a grant for the specific research "The study of the development of organisms effective to environmental conservation for human life" at Okayama University in 1998-1999.

\section{Literature cited}

1. Arachevaleta, M., Bacon, W.C., Hoveland, C.S. and Radcliffe, D.E. (1989). Effect of the tall fescue endophyte on plant response to environmental stress. Agron. J. $81: 83-90$.

2. Clay, K. (1990). Fungal endophytes of grasses. Annu. Rev. Ecol. Syst. 21: 275-297.

3. Comai, L. and Kosuge, T. (1982). Cloning and characterization of iaaM, a virulence determinant of Pseudomonas savastanoi. J. Bacteriol. 148: 40-46.

4. Latch, G.C.M. and Christensen, M.J. (1985). Artificial infection of grasses with endophytes. Ann. appl. Biol. $107: 17-24$.

5. Murray, F.R., Latch, G.C.M. and Scott, D.B. (1992). Surrogate transformation of perennial ryegrass, Lolium perenne, using genetically modified Acremonium endophyte. Mol. Gen. Genet. 233 : 1-9.

6. Rice, J.S., Pinkerton, B.W., Stringer, W.C. and Undersander, D.J. (1990). Seed production in tall fescue as affected by fungal endophyte. Crop Sci. $30: 1303-1305$.

7. Sambrook, J., Fritsch, E.F. and Maniatis, T. (1989). Molecular Cloning. A Laboratory Manual, 2nd ed., Cold Spring Harbor Laboratory Press, Cold Spring Harbor, New York, pp. 21-100.

8. Schardl, C.L., Liu, J.S., White, J.F., Jr., Finkel, R.A., An, Z.Q. and Siegel, M.R. (1991). Molecular phylogenetic relationships of non-pathogenic grass mycosymbionts 
and clavicipitaceous plant pathogens. Plant Syst. Evol. 178: $27-41$.

9. Scott, D.B. and Schardl, C.L. (1993). Fungal symbionts of grasses : evolutionary insights and agricultural potential. Trends Microbiol. 1: 196-200.

10. Siegel, M.R., Latch, G.C.M., Bush, L.P., Fannin, F.F., Rowan, D.D., Tapper, B.A., Bacon, C.W. and Johnson, M.C. (1990). Fungal endophyte-infected grasses: alkaloid accumulation and aphid response. J. Chem. Ecol. $16: 3301-3315$.

11. Siegel, M.R. and Schardl, C.L. (1991). Fungal endophytes of grasses: detrimental and beneficial associations. In Microbial Ecology of Leaves (Andrew, J.H. and Hirano, S.S. eds.), Springer Verlag, Berlin, pp. 198-221.

12. Vollmer, S.J. and Yanofsky, C. (1986). Efficient cloning of genes of Neurospora crassa. Proc. Natl. Acad. Sci. USA $83:$ 4869-4873.

13. Yamada, T. (1993). The role of auxin in plant-disease development. Annu. Rev. Phytopathol. 31 : 253-273.

14. Yelton, M.M., Hamer, J.E. and Timberlake, W.E. (1984). Transformation of Aspergillus nidulans by using a $\operatorname{trp} C$ plasmid. Proc. Natl. Acad. Sci. USA 81 : 1470-1474.

15. Yoder, O.C. (1988). Cochliobolus heterostrophus, cause of southern corn leaf blight. In Genetics of Plant Patho- genic Fungi (Sidhu, G.S. ed.), Academic Press, San Diego, pp. 93-112.

\section{和 文 摘 要}

Ahmad YUNUS・川又伸治・島貫忠幸・村上泰弘・一瀬勇規・ 白石友紀・山田哲治：ネオティフォディウム・エンドファイト への $i a a M$ 遺伝子形質転換体の作出

オリーブこぶ病細菌の i $a a M$ 遺伝子 (トリプトファンモノオ キシゲナーゼ遺伝子）をネオティフォディウム・エンドファイ 卜菌に導入し形質転換を試みた。その結果, ポリエチレングリコ ール (PEG) を用いる方法がエレクトロポレーション法に比べ て高い形質転換効率を示した。ネオティフォディウム TF91006 株と Ti91093 株の形質転換体における iaaM 遺伝子と薬凨耐性 マーカーのハイグロマイシン耐性遺伝子の染色体 DNA への組 込みは，PCR 法によって予想される $560 \mathrm{bp}$ の iaaM 遺伝子と $1.7 \mathrm{~kb}$ のハイグロマイシン耐性遺伝子の増幅によって確認し た。これらの形質転換体における iaaM 遺伝子の発現を培養ろ 液中に蓄積されたインドールアセトアミド (IAM) 量を HPLC によって定量することによって調べたところ，多くの形質転換 体では有意な IAM の蓄積が検出された。

(Received August 31, 1998 ; Accepted December 18, 1998) 